\title{
UPAYA MENINGKATAN KEMAMPUAN GURU DALAM MENGGUNAKAN KOMPUTER PADA PEMBELAJARAN MELALUI PELATIHAN TIK DI SMK NEGERI 1 MESUJI RAYA
}

\author{
Mustaridi \\ Kepala Sekolah SMK Negeri 1 Mesuji Raya \\ mustaridi@gmail.com
}

\begin{abstract}
ABSTRAK
Penelitian ini bertujuan untuk meningkatkan kemampuan guru dalam menggunakan komputer melalui pelatihan TIK pada SMK Negeri 1 Mesuji Raya. Penelitian ini tergolong penelitian tindakan sekolah dengan melibatkan 10 orang guru SMK Negeri 1 Mesuji Raya. Penelitian dilakukan dengan dua siklus dan masing-masing siklus terdiri atas empat tahapan, yakni: perencanaan, pelaksanaan, observasi dan refleksi. Indikator kinerja yang ditetapkan adalah: Guru berhasil dalam melaksanakan penilaian kelas bila guru sudah memenuhi kereteria memperoleh skor lebih atau sama dengan 77 (dengan kategori baik). Dari hasil analisi terjadi peningkatan kemampuan guru dalam menggunakan komputer melalui melalui pelatihan TIK pada SMK Negeri 1 Mesuji Raya dari siklus I yaitu kemampuan guru menggunakan komputer sebesar kategori cukup dan kemampuan guru dalam menggunakan Komputer dengan kategori baik pada siklus II. Dengan demikian dapat disimpulkan bahwa melalui Pelatihan TIK dapat meningkatkan kemampuan guru dalam Menggunakan Komputer pada SMK Negeri 1 Mesuji Raya.
\end{abstract}

Kata kunci: Kemampuan Guru , Komputer, Pelatihan TIK

\section{ABSTRACT}

This study aims to improve the ability of teachers to use computers through ICT training at SMK Negeri 1 Mesuji Raya. This research is classified as a school action research involving 10 teachers of SMK Negeri 1 Mesuji Raya. The research was conducted in two cycles and each cycle consisted of four stages, namely: planning, implementing, observing and reflecting. The determined performance indicators are: The teacher is successful in carrying out the classroom assessment if the teacher has met the criteria for a score of more than or equal to 77 (with a good category). From the results of the analysis, there was an increase in the ability of teachers to use computers through ICT training at SMK Negeri 1 Mesuji Raya from the first cycle, namely the ability of teachers to use computers at sufficient category and the ability of teachers to use computers with good categories in cycle II. Thus it can be concluded that through ICT training can improve the ability of teachers to use computers at SMK Negeri 1 Mesuji Raya.

Keywords: Teacher Ability, Computers, ICT Training 


\section{PENDAHULUAN}

Pendidikan nasional adalah pendidikan yang berdasarkan Pancasila dan Undang-Undang Dasar Negara Republik Indonesia Tahun 1945 yang berakar pada nilai-nilai agama, kebudayaan nasional Indonesia dan tanggap terhadap tuntutan perubahan zaman. Sedangkan sistem pendidikan nasional adalah keseluruhan komponen pendidikan yang saling terkait secara terpadu untuk mencapai tujuan pendidikan nasional.

Dengan adanya Globalisasi, kehidupan manusia menjadi lebih mudah, efektif, dan hemat. Arus modernisasi dan globalisasi itu mempunyai banyak nilai positif dan negatifnya. Segi positifnya, informasi yang didapat menjadi lebih cepat dan akurat daripada masa-masa sebelumnya yang kebanyakan masih menggunakan cara-cara manual. Selain itu, semua orang juga merasa senang apabila ikut serta terhadap perkembangan zaman dan tidak mau dikatakan ketinggalan zaman. Globalisasi adalah suatu proses menjadikan sesuatu (benda atau perilaku) sebagai ciri dari setiap individu di dunia ini tanpa dibatasi oleh wilayah.

Teknologi media komunikasi memang memberi kemudahan dalam hidup. Manusia tidak perlu lagi membuang waktu, biaya dan tenaga yang besar hanya untuk berkomunikasi dengan orang lain dimanapun mereka berada. Akan tetapi, setiap hal atau benda pasti memiliki nilai positif dan negatifnya. Dibalik semua keuntungan yang di dapat dari teknologi media komunikasi seperti komputer. Pada kenyataannya ada sebagian orang yang belum memanfaatkan fungsi dari adanya komputer. Padahal sekarang ini hamper sebagian besar pekerjaan maupun pendidikan bergantung pada komputer. Semua itu menuntut setiap individu untuk dapat mengoperasikan kompuer sebagai konsekuensi hidup di zaman serba canggih ini. Komputer sebagai media pembelajaran mulai diterapkan pada dunia pendidikan. Perkembangan teknologi informasi saat ini telah menjalar dan memasuki setiap dimensi aspek kehidupan manusia. Teknolgi informasi saat ini 
memainkan peran yang besar didalam kegiatan bisnis, perubahan sturktur organisasi, dan mannajemen organisasi. Dilain pihak, teknologi informasi juga memberikan peranan yang besar dalam pengembangan keilmuan dan menjadi sarana utama dalam suatu institusi akademik.

\section{Perkembangan}

IPTEK terhadap proses pembelajaran adalah diperkayanya sumber belajar dan media pembelajaran. Media komputer dimanfaatkan dalam pembelajaran karena memberikan keuntungan-keuntungan yang tidak dimiliki oleh media pembelajaran lainnya yaitu kemampuan komputer untuk berinteraksi secara individu dengan siswa. Oleh karena itu kami akan membahas bagaimana Manfaat komputer dan Internet sebagai meadia pembelajaran.

SMK Negeri 1 Mesuji Raya memiliki tenaga pendidik dan kependidikan antara lain 11 orang, 1 orang TU, kesemuanya itu terbagi 6 rombel. Guru-guru SMK Negeri 1 Mesuji Raya pada umumnya memiliki komputer atau Laptop, akan tetapi kemampuan mereka alam mengoperasikannya maih belum maksimal. Guru yang punya Laptop
6, yang bisa mengoperasikan laptop 6 , yang mahir menggunakan laptop 3 orang namun belum menggunakannya pada saat proses belajar mengajar.

Pada saat observasi di kelas, umumnya guru tidak menggunakan media pembelajaran yang efektif seperti menggunakan komputer pada saat proses belajar mengajar berlangsung. Secara umum kemampuan guru dalam pengelolaan kelas cukup memadai namun metode dan media yang digunakan dalam kegiatan pembelajaran belum tepat dan monoton. Sehingga interaksi dan komunikasi yang dikembangkan dengan peserta didik masih satu arah. Akibat yang timbul dari proses pembelajaran tersebut adalah minat belajar siswa menjadi sangat rendah dan kurang memuaskan di karenakan tidak menarik dan menyenangkan bagi siswa. Kondisi inilah yang sangat memprihatinkan bagi sekolah dimana pada saat ini semua di lakukan berdasarkan IT. Berdasarkan latar belakang yang dipaparkan diatas penulis tertarik mengambil judul "Upaya Meningkatan Kemampuan Guru Dalam Menggunakan Komputer Pada 
Pembelajaran Melalui Pelatihan TIK

SMK Negeri 1 Mesuji Raya".

Berdasarkan pembahasan masalah yang dikemukakan diatas, masalah penelitian ini dapat dirumuskan sebagai berikut Adakah upaya untuk mengetahui peningkatan kemampuan guru dalam menggunakan komputer pada pembelajaran melalui pelatihan TIK ?.Adapun tujuan penelitian tindakan sekolah adalah untuk meningkatkan kemampuan guru dalam penggunaan komputer dalam pembelajaran, selain itu guru juga diharapkan pada saat proses pembelajaran melalui pelatihan TIK dapat menggunakan media yang tepat dan efektif dan menyenangkan bagi siswa.

Selain itu penelitian ini juga mempunyai beberapa tujuan antara lain : Untuk mengetahui peningkatan guru dalam memanfaatkan komputer pada waktu proses belajar mengajar. Untuk mengetahui peningkatan hasil belajar siswa pada pembelajaran dengan menggunakan komputer di SMK Negeri 1 Mesuji Raya Kecamatan Mesuji Raya Kabupaten Ogan Komering Ilir.

\section{KAJIAN PUSTAKA}

\section{Pengertian Guru}

Dalam dunia pendidikan, guru adalah merupakan faktor vital dalam pelaksanaan pendidikan, karena ia akan dapat memberikan makna terhadap masa depan anak didik. Untuk mewujudkan semua itu, guru diberikan tugas dan tanggung jawab terhadap keberhasilan pendidikan. Undang-Undang Repuplik Indonesia Nomor 14 Tahun 2005 pada pasal 35 menyebutkan, Beban kerja guru mencakup kegiatan pokok yaitu merencanakan pembelajaran, melaksanakan pembelajaran, menilai hasil belajar, membimbing dan melatih peserta didik, serta melaksanakan tugas tambahan (UURI, 2005:21).

Guru adalah tenaga fungsional yang bertugas khusus untuk mengajar, mendidik, melatih dan menilai hasil pembelajaran peserta didik serta efektifitas mengajar guru. Tugas guru adalah profesional, maka dari itu diharapkan dapat melaksanakan tugas dengan baik. Karena profesi itu pada hakekatnya status pernyataan atau janji terbuka, bahwa seseorang akan mengabdikan dirinya pada status 
jabatan atau pekerjaan dalam arti biasa, sehingga pernyataan yang dibuatnya baik bagi orang lain juga baik bagi dirinya.

\section{Peraturan Pemerintah}

No.19 Tahun 2005 tentang Standar Nasional Pendidikan menyatakan, pendidik (guru) harus memiliki kualifikasi akademik dan kompetensi sebagai agen pembelajaran, sehat jasmani dan rohani, serta memiliki kemampuan untuk mewujudkan tujuan pendidikan nasional.

Pada Kepmenpan No. 26/Menpan1989 tentang Angka kredit jabatan guru dalam lingkungan Depdikbud pasal 1 (a) guru adalah Pegawai Negeri Sipil yang diberi tugas, wewenang dan tanggung jawab oleh pejabat yang berwenang untuk melaksanakan pendidikan di sekolah (Joni, 1992 : 86).

$$
\text { Suwarno (2006 : 37) }
$$

menyatakan Pendidik adalah orang yang dengan sengaja memengaruhi orang lain untuk mencapai tingkat kemanusiaan yang lebih tinggi. Dengan kata lain, pendidik adalah orang yang lebih dewasa yang mampu membawa peserta didik kearah kedewasaan.
Sardiman, AM (2003 : 125) menyatakan guru adalah salah satu komponen manusia dalam proses belajar-mengajar, yang ikut berperan dalam usaha pembentukan sumber daya manusia yang potensial di bidang pembangunan. Oleh karena itu guru merupakan salah satu unsur di bidang pendidikan harus berperan serta secara aktif dalam menempatkan kedudukannya sebagai tenaga professional, sesuai dengan tuntutan masyarakat yang semakin berkembang.

\section{Pengertian Komputer Pada Pembelajaran} Istilah komputer mempunyai arti yang luas dan berbeda untuk orang yang berdeda.Kata komputer (computer) berasal dari bahasa latin computare yang berarti menghitung. Berikut beberapa pengertian komputer (Sutarman, 2009) adalah sebagai berikut:

a. Menurut buku Computer Annual (Robert H. Blissmer), Komputer adalah suatu alat elektronik yang mampu melakukan beberapa tugas sebagai berikut : Menerima 
input, Memproses input tadi sesuai dengan programnya, Menyimpan perintah-perintah dan hasil dari pengolahan, Menyediakan output dalam bentuk informasi.

b. Menurut buku Computer Today (Donald H. Sanders), Komputer adalah sistem elektronik untuk memanipulasi data yang cepat dan tepat serta dirancang dan diorganisasikan agar secara otomatis menerima dan menyimpan data input, memprosesnya, dan menghasilkan output di bawah pengawasan suatu langkahlangkah instruksi program yang tersimpan pada memori.

c. Menurut buku Computer Organization (V.C. Hamacher, ZG. Vranesic, S.G. Zaky)

Sardiman, menyatakan bahwa media pembelajaran mempunyai kegunaankegunaan sebagai berikut :

1. Memperjelas penyajian pesan agar tidak terlalu bersifat verbalisasi (dalam bentuk katakata tertulis atau lisan).

2. Mengatasi keterbatasan ruang, waktu dan daya indera.
3. Dengan menggunakan media pembelajaran secara tepat dan bervariasi dapat mengatasi sikap pasif anak didik.

Penguasaan ketrampilan menggunakan komputer dikategorikan dalam beberapa bagian, antara lain :

a. Penguasaan sistem operasi komputer, contohnya Windows

b. Pengolahan dokumen, contoh: Microsoft Word

c. Pengolahan data administrasi, contoh: Microsoft Excel

d. Pembuatan media pembelajaran, contoh: Microsoft Power point

e. Pengeksplorasian internet: browsing, searching, email dan blogging.

Komputer (Wikipedia.org)

adalah alat yang dipakai untuk mengolah data menurut prosedur yang telah dirumuskan. Kata Komputer semula dipergunakan untuk menggambarkan orang yang perkerjaannya melakukan perhitungan aritmatika, dengan atau tanpa alat bantu, tetapi arti kata ini kemudian dipindahkan kepada mesin itu sendiri. Asal 
mulanya, pengolahan informasi hampir eksklusif berhubungan dengan masalah aritmatika, tetapi komputer modern dipakai untuk banyak tugas yang tidak berhubungan dengan matematika.

Contoh penggunaan internet ini adalah digunakan oleh Universitas terbuka dalam penyelenggaraan Universitas Terbuka Jarak Jauh disamping siswa mendapat modul untuk proses belajar mengajar dia juga dapat mengakses informasi melalui internet. Kuliah lewat Internet oleh IBU teledukasi.com. Universitas virtual IBU teledukasi ini didirikan oleh Adi sasono, Ketua Ikatan Cendekiawan Muslim Indonesia (ICMI) bekerjasama dengan Universitas Tun Abdul Razak (Unitar) Malaysia yang sudah lebih dulu menyelenggarakan perkuliahan online.

Pada pendidikan jarak jauh

Fakultas Kedokteran Universitas Gajah Mada. Interaksi pembelajaran pada program Magister Manajemen Rumah Sakit dan Magister Manajemen Pelayanan Kesehatan dilakukan melalui surat elektronik (email) siswa harus menjawab $75 \%$ pertanyaan melalui e-mail. Contoh lain pemanfaatan jaringan komputer dilakukan di Universitas Indonesia (UI). Sejak tahun 1994 UI telah mengembangkan infrastruktur informasi yang dikenal dengan nama Jaringan Universitas Indonesia Terpadu (JUITA). JUITA menghubungkan sebelas fakultas dan lembaga-lembaga penting yang ada di UI dengan menggunakan jaringan serat optik ( Sri Hartati, dkk 1997 dalam Benny A. Pribadi dan Rosita, Tita, 2000).

\section{METODOLOGI PENELITIAN}

Penelitian Tindakan Sekolah (PTS) ini dilakukan di SMK Negeri 1 Mesuji Raya yang berlamat di Jalan Fatmawati Blok B desa Kemang Indah Kecamatan Mesuji Raya Kabupaten Ogan Komering Ilir Provinsi Sumatera Selatan. Penelitian Tindakan Sekolah (PTS) ini dilakukan oleh peneliti selama 3 bulan yaitu dari bulan September sampai dengan bulan November 2019 dengan 2 siklus kegiatan. Siklus pertama di laksanakan pada 4 September 2019 dan 18 September 2019 siklus yang kedua dilaksanakan pada tanggal 9 Oktober 2019 dan 23 Oktober 2019. Subyek 
penelitan adalah guru mata pelajaran yang ada di lingkungan SMK Negeri 1 Mesuji Raya yang merupakan tempat penulis bertugas sehari-hari. Adapun jumlah guru mapel yang dijadikan subyek penelitian adalah sebanyak 10 orang.Alasan Peniliti memilih subyek penelitian dikarenakan secara keseluruhan, guru pada umumnya memiliki kemampuan penggunaan komputer yang sedang, sehingga perlu ditingkatkan lagi. Langkah-langkah PTS yang Peneliti laksanakan merupakan satu siklus yang terdiri dari empat tahap sesuai dengan langkah-langkah PTS yang dikemukakan oleh Wardhani (2008), yaitu merencanakan perbaikan, melaksanakan tindakan, mengamati (observasi), dan melakukan refleksi.

Sesuai dengan langkahlangkah PTS maka pada tahap awal, Peneliti mempersiapkan materi yang akan disajikan, menyusun perencanaan pembelajaran komputer, serta menyiapkan alat dan media pembelajaran yang sesuai. Setelah melalui tahap persiapan, Peneliti masuk ketahap tindakan yang merupakan perbaikan pembelajaran yang dibagi masing-masing dalam dua siklus. Dan prosedur selanjutnya Peneliti melakukan pengamatan, sedangkan perosedur terakhir dalam Penelitian Tindakan Sekolah ini adalah melakukan refleksi.

\section{HASIL DAN PEMBAHASAN}

\section{Hasil Penelitian}

Pemahaman guru dalam menggunakan IT akan menunjukan meningkatnya kompetensi yang ada dalam dirinya. Pemahaman tersebut ditentukan dengan standar keberhasilan pemahaman yaitu pencapaian skor harapan senilai 7 dari jumlah skor hasil observasi. Dari skor tersebut maka dapat disimpulkan bahwa guru sudah meningkat kompetensinya atau belum setelah mengikuti workshop IT mengenai penggunaan TIK sebagai media mengajar.

Hasil dari observasi pada siklus ke I ini perolehan skor mencapai nilai 56. Skor perolehan tersebut sudah melebihi dari skor harapan yaitu 50, namun masih jauh memenuhi skor maksimal yaitu 90 . Namun meskipun demikan pelaksanaan workshop TIK dalam meningkatkan kompetensi guru dalam hal penggunaan TIK sebagai media mengajar pada siklus I ini 
berjalan dengan cukup baik. Hal ini terlihat pada hasil observasi yang menunjukan adanya peningkatan kompetensi oleh para guru meskipun belum terlalu tinggi.

Dari reaksi dan tanggapan guru, dapat dinyatakan bahwa workshop TIK mampu

meningkatkan semangat

guru dalam mempelajari penggunaan TIK sebagai media mengajar di SMK Negeri 1 Mesuji Raya.

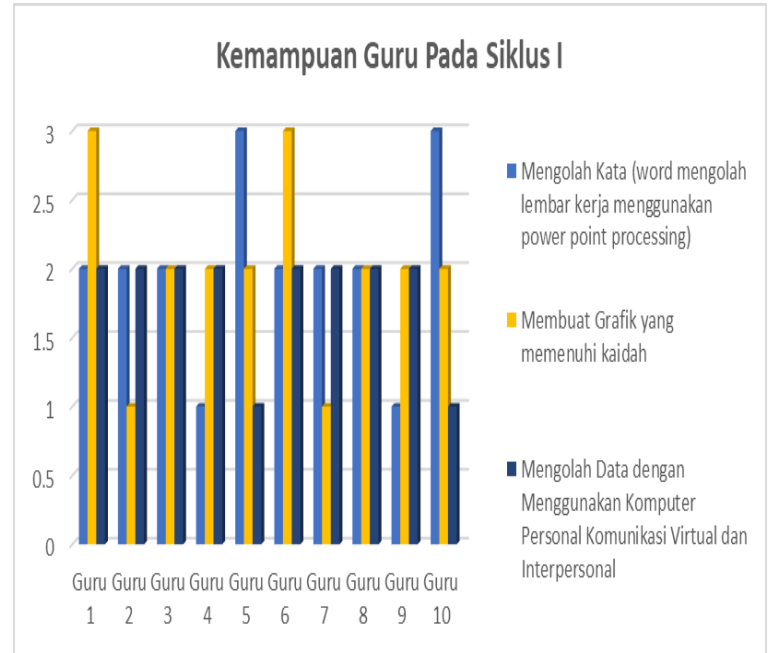

Dari data statistik diatas dapat dengan jelas terlihat kemampuan guru dengan penilaian pada bidang-bidangnya masingmasing. Pada penilaian bagian pertama Mengolah Kata (word mengolah lembar kerja menggunakan power point processing) rata-rata kemampuan guru mendapatkan skor 1 sebanyak 2 orang dan 6 orang dengan skor 2 dan 2 orang dengan skor 3. Pada penilaian bagian kedua Membuat Grafik yang memenuhi kaidah ratarata kemampuan guru mendapatkan skor 2 sebanyak 6 orang dan 2 orang dengan skor 1 dan 2 orang dengan skor 3. Pada penilaian bagian ketiga Mengolah Data dengan Menggunakan Komputer Personal Komunikasi Virtual dan Interpersonal rata-rata kemampuan guru mendapatkan skor 2 sebanyak 6 orang dan 4 orang dengan skor 2 .

Hasil pengamatan terhadap guru dan dari analisis data di atas jelas hasil dari observasi pada siklus ke II ini sudah terjadi peningkatan kompetensi guru dalam hal penggunaan TIK sebagai media mengajar. Terbukti dari pencapaian skor hasil observasi adalah 86. Skor perolehan tersebut lebih tinggi dari skor harapan yaitu 50. Hal tersebut membuktikan bahwa pelaksanaan workshop TIK dalam meningkatkan kompetensi guru pada penggunaan TIK sebagai media mengajar pada siklus II sudah sesuai harapan. Jadi, dengan dilaksanakannya workshop TIK pada siklus II, maka guru mata 
pelajaran di SMK Negeri 1 Mesuji

Raya maka dapat diindikasikan bahwa kompetensi guru telah meningkat.

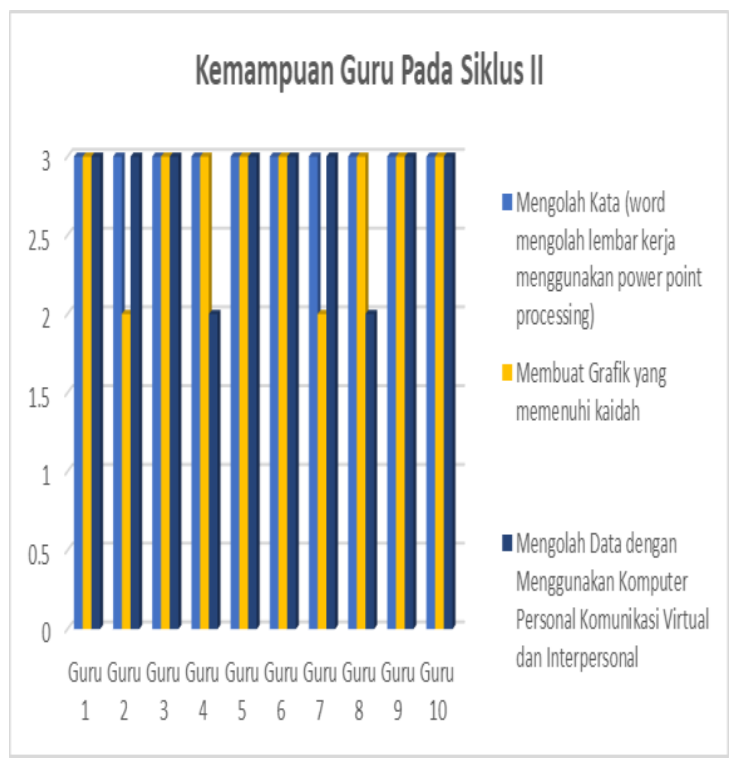

Dari data statistik diatas dapat dengan jelas terlihat kemampuan guru dengan penilaian pada bidang-bidangnya masingmasing. Pada penilaian bagian pertama Mengolah Kata (word mengolah lembar kerja menggunakan power point processing) rata-rata kemampuan semua guru mendapatkan skor 3 sebanyak 10 orang. Pada penilaian bagian kedua membuat grafik yang memenuhi kaidah rata-rata kemampuan guru mendapatkan skor 3 sebanyak 8 orang dan 2 orang dengan skor 2. Pada penilaian bagian ketiga Mengolah Data dengan Menggunakan Komputer Personal Komunikasi Virtual dan Interpersonal rata-rata kemampuan guru mendapatkan skor 3 sebanyak 8 orang dan 2 orang dengan skor 2 .

\section{Pembahasan}

Hasil penelitian yang peneliti peroleh, sebagai data awal adalah nilai tes yang diperoleh sebelum peneliti lakukan tindakan melalui metode pendampingan. Sedangkan nilai tes diakhir siklus kesatu,peneliti peroleh setelah peneliti lakukan tindakan, dimana sebelumnya peneliti sudah membimbing peserta bimbingan melalui metode pendampingan juga untuk memudahkan peserta bimbingan peneliti juga menggunakan metode diskusi dan metode penyelesaian masalah.

Kepada peserta bimbingan peneliti mengingatkan langkah awal dan membagikan contoh format cara mengidentifikasi masalah dan menentukan judul berdasarkan identifikasi masalah.

Agar lebih jelas lagi dapat kita lihat peningkatan kemampuan guru dari Silus I dan Siklus II pada fase penilaian petama yaitu 
Kemampuan Guru Pada Mengolah Kata (word mengolah lembar kerja menggunakan power point processing) melalui tabel statistik di bawah ini:

Kemampuan Guru Pada Mengolah Kata (word mengolah lembar kerja menggunakan power point processing)

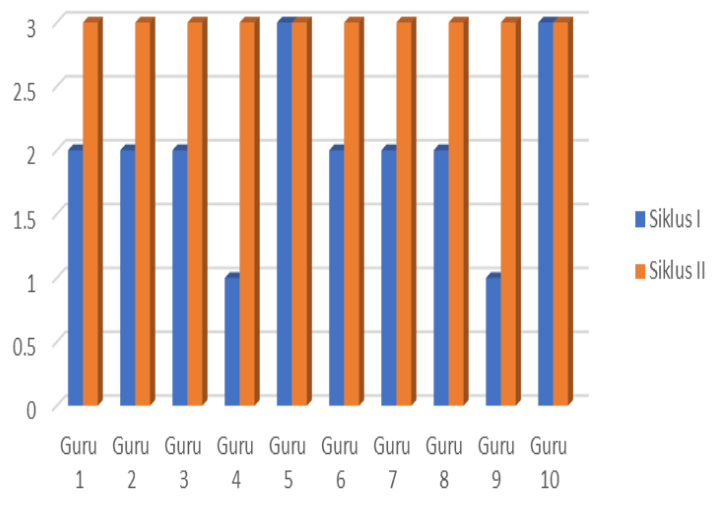

Selanjutnya dapat kita lihat peningkatan kemampuan guru dari Siklus I dan Siklus II pada fase penilaian kedua yaitu membuat grafik yang memenuhi kaidah melalui tabel statistik di bawah ini:

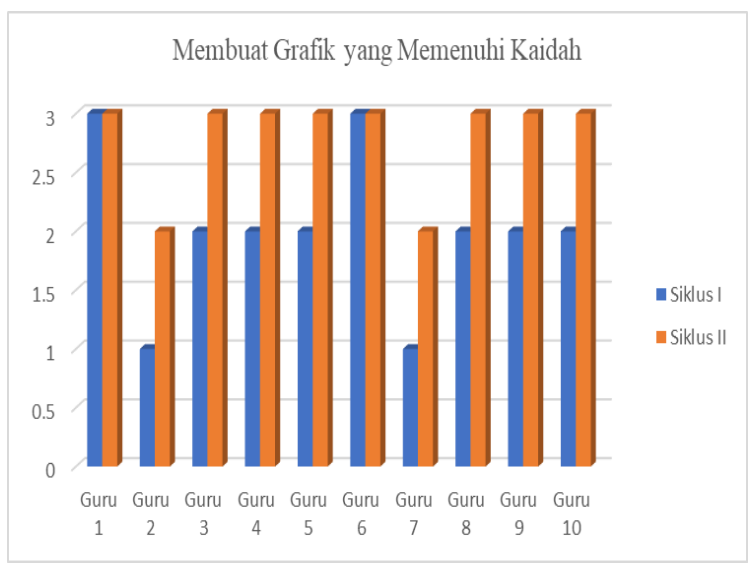

Kemudian dapat kita lihat peningkatan kemampuan guru dari
Siklus I dan Siklus II pada fase penilaian ketiga yaitu Mengolah Data dengan Menggunakan Komputer Personal Komunikasi Virtual dan Interpersonal melalui tabel statistik di bawah ini:

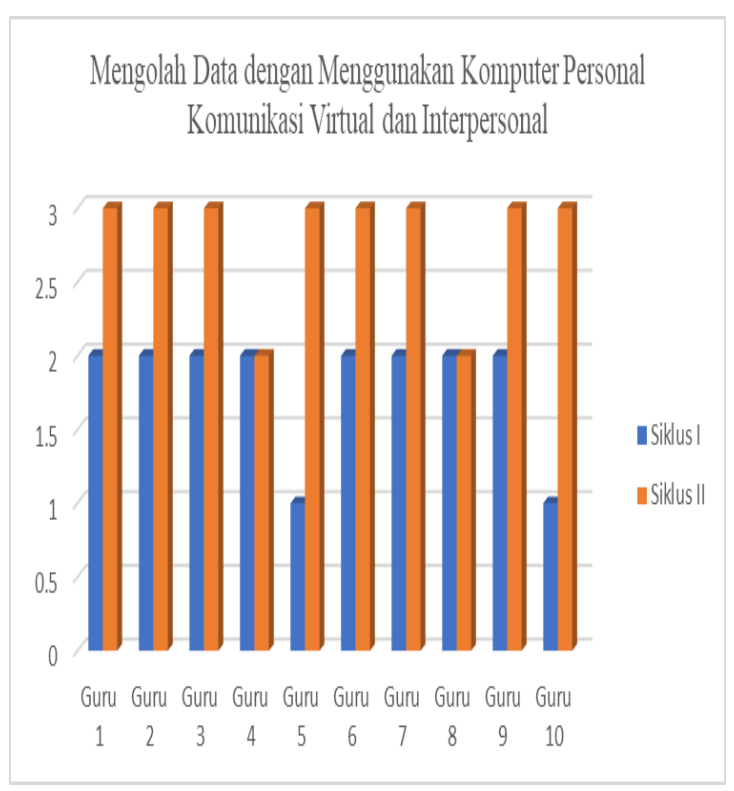

\section{KESIMPULAN DAN SARAN}

\section{Kesimpulan}

Berdasarkan pada paparkan di atas, simpulan dari penelitian ini adalah sebagai berikut: Melalui pelatihan TIK para guru dapat menambah wawasan tentang kemajuan teknologi komputer melalui program-program yang dipelajari.Dengan memahami teknologi, guru mendapatkan banyak kemudahan dalam melaksanakan tugas mengajar di kelas. Pelatihan TIK menjaikan pekerjaan guru lebih 
mudah dalam membuat perangkat pembelajaran dan mengolah nilai serta pengisian aplikasi E-Raport.

\section{Saran}

Untuk rekan Kepala Sekolah, hendaknya dapat lebih memperhatikan peningkatan kemampuan guru-guru pada sekolahnya sehingga dapat kinerja masing-masing individu. Untuk guru, hendaknya selalu bersemangat dalam meningkatkan kemampuan individu, terutama dalam menggunakan teknologi yang sesuai dengan zaman yang ada.

\section{DAFTAR PUSTAKA}

Departemen Pendidikan Nasional.

2005. Undang-Undang

Republik Indonesia, Nomor 14 Tahun 2005 Tentang Guru dan Dosen. Depdiknas RI : Jakarta.

Joni, Raka. 1992. Peningkatan Mutu Pendidikan Dasar dan Menengah Melalui Strategi Pembelajaran Aktif (Cara Belajar Siswa Aktif) dan Pembinaan Profesional Guru, Kepala Sekolah serta Pembina Lainnya. Jakarta: Rinehart and Wiston.

Pribadi, Benny A. dan Rosita, Tita. Prospek Komputer Sebagai Media Pembelajaran Interaktif Dalam System
Pendidikan Jarak Jauh di Indonesia. jurnal pendidikan. Sardiman, A.M. 2002. Intekasi Dan Motivasi Belajar Mengajar. Jakarta: Raja Grafindo Persada.

Sardiman, AM. 2003. Interaksi dan Motivasi Belajar Mengajar . Jakarta: Rajawali Press.

Sutarman. (2009). Pengantar

Teknologi Informasi. Jakarta: Bumi Aksara.

Suwarno, Wiji. 2006. Dasar-Dasar Ilmu Pendidikan. Jogjakarta : AR-Ruzz Media Jogjakarta. 